\title{
Degradation of hydroquinone, gentisate, and benzoate by a fermenting bacterium in pure or defined mixed culture
}

\author{
Ulrich Szewzyk* and Bernhard Schink*** \\ Fakultät für Biologie, Universität Konstanz, D-7750 Konstanz, Federal Republic of Germany
}

\begin{abstract}
From a methanogenic fixed-bed reactor fed with hydroquinone as sole energy and carbon source, a rodshaped bacterium was isolated in pure culture which could degrade hydroquinone and gentisate (2,5-dihydroxybenzoate). In syntrophic coculture with either Desulfovibrio vulgaris or Methanospirillum hungatei, also benzoate could be degraded. Other substrates such as sugars, fatty acids, alcohols, and cyclohexane derivatives were not degraded. Sulfate, sulfite, or nitrate were not used as external electron acceptor. The isolate was a Gram-negative, non-motile, nonsporeforming strict anaerobe; the guanine-plus-cytosine content of the DNA was $53.2 \pm 1.0 \mathrm{~mol} \%$. In pure culture, hydroquinone was degraded to acetate and benzoate, probably via an intermediate carboxylation. In syntrophic mixed cultures, all three substrates were converted completely to acetate. Phenol was never detected as a fermentation product.
\end{abstract}

Key words: Anaerobic degradation - Benzoate - Hydroquinone - Gentisate - Aromatic compounds Carboxylation - Reductive dehydroxylation - Interspecies hydrogen transfer

Degradation of aromatic compounds under anaerobic conditions has been reported repeatedly since 1932 (for review, see Evans 1977; Sleat and Robinson 1984; Young 1984). Most of these studies dealt with degradation of aromatic compounds in sludge samples or undefined enrichment cultures. Pure culture studies have mostly been done with phototrophic, sulfate reducing, and denitrifying bacteria (Bak and Widdel 1986; Szewzyk and Pfennig 1987; Tschech and Fuchs 1987; Widdel 1988). By contrast, only few data are available on degradation of aromatic compounds by fermenting bacteria. Pure cultures of fermenting bacteria degrading trihydroxybenzenoids and trihydroxybenzoate have recently been described (Tsai and Jones 1975; Schink and Pfennig 1982; Krumholz and Bryant 1986), and degra-

\footnotetext{
* Present address and address for offprint requests: University of Göteborg, Dept. of Marine Microbiology, Carl Skottsbergs Gata 22, S-41319 Göteborg, Sweden

** Present address: Universität Tübingen, Lehrstuhl für Mikrobiologie I, Auf der Morgenstelle 28, D-7400 Tübingen, FRG
}

dation of resorcinol to acetate and butyrate was reported for defined mixed cultures (Tschech and Schink 1985). Two bacteria have been described degrading benzoate in syntrophic coculture with a hydrogen-consuming bacterium (Mountfort et al. 1984; Tschech and Schink 1986). No fermenting bacterium degrading phendiols has been isolated in pure culture, but degradability of these compounds under methanogenic conditions has been observed in enrichment cultures and sludge samples (Szewzyk et al. 1985; Young and Rivera 1985).

In this paper, we report on the isolation of a hydroquinone- and gentisate-fermenting bacterium which also catabolized benzoate when grown in coculture with either a sulfate-reducing or a methanogenic bacterium.

\section{Material and methods \\ Source of organisms}

Strain HQGö1 was isolated from the enrichment culture HQGö described in an earlier study (Szewzyk et al. 1985), which was originally inoculated with anoxic digestor sludge from the municipal sewage plant in Göttingen, FRG.

\section{Media and growth conditions}

The freshwater medium used for cultivation and isolation was essentially the same as described previously (Widdel and Pfennig 1981; Schink and Pfennig 1982). Trace element solution SL10 (Widdel et al. 1983), selenite/tungstate solution (Tschech and Pfennig 1984), 6 vitamin solution and vitamin B12 solution (Pfennig 1978) were added from sterile stock solutions to the medium after autoclaving. Hydroquinone, sodium benzoate and sodium gentisate were added from filter-sterilized stock solutions which were kept under $\mathrm{N}_{2}$ atmosphere. In addition to sulfide, dithionite was added (about $100 \mu \mathrm{mol} / \mathrm{l}$ ) as a further, strong reducing agent before inoculation. Strain HQGö1 was isolated using the deep agar culture technique (Pfennig 1978). Purity was checked by microscopic examination and by growth tests in complex medium (AC medium; Difco Laboratories, Detroit, MI, USA).

Growth tests were carried out in duplicates at $28^{\circ} \mathrm{C}$ in liquid cultures in $20 \mathrm{ml}$ screw cap tubes. Growth was followed by measuring the turbidity in a Spectronic 70 
spectrophotometer (Bausch \& Lomb, Rochester, NY, USA). Several substrates were tested for degradation in the presence of sulfate and Desulfovibrio vulgaris strain Marburg as hydrogen scavenger.

\section{Chemical analyses}

Aromatic compounds were quantified by recording absorption spectra in diluted medium samples with a Gilford 250 spectrophotometer. For quantitation of benzoate which absorbs in the same wavelength range as sulfide, zinc acetate solution was added to the sample $(100 \mu 1$ of a $1 \mathrm{M} \mathrm{Zn-acetate}$ solution to $1.4 \mathrm{ml} \mathrm{sample)} \mathrm{before} \mathrm{measurement} \mathrm{to} \mathrm{precipitate}$ the $\mathrm{H}_{2} \mathrm{~S}$. In addition, phenol was identified and quantified by gas chromatography (Schink and Pfennig 1982), benzoate by high-pressure liquid chromatography on an ultrasphere reversed-phase column (Beckman Instruments, München, FRG).

Fermentation products were identified and measured by gas chromatography as described earlier (Schink and Pfennig 1982). Sulfide was determined photometrically by the methylene blue method (Cline 1969).

Hydrogen in the culture medium was measured by gas chromatography with a detector based on the HgO-to-Hg vapour conversion technique (Seiler et al. 1980).

All chemicals used were of reagent grade purity and obtained from Merck, Darmstadt, FRG, and Fluka, NeuUlm, FRG.

\section{Results \\ Isolation and cultivation}

The hydroquinone-degrading strain HQGö1 was isolated from an anaerobic fixed bed reactor inoculated with a liquid enrichment culture which had been cultivated for more than two years with hydroquinone as sole energy and carbon source (Szewzyk et al. 1985). In this highly enriched mixed culture, a stable community had developed which consisted mainly of the hydroquinone-degrading bacteria and two types of methanogenic bacteria, namely, Methanospirillum sp. and Methanothrix sp. The same bacterial population was observed in the continuously operated fixed bed reactor, where it formed a thick biofilm of the filling material (manuscript in preparation). Isolation of the hydroquinone degrader was only possible if the redox potential in the deep agar cultures was lowered by addition of about $100 \mu \mathrm{M}$ dithionite. Addition of yeast extract, rumen fluid, or casamino acids never stimulated growth of the hydroquinone-degrading bacterium in the agar cultures.

The isolate obtained after two deep agar dilution series was further cultivated in sulfide-prereduced freshwater medium with hydroquinone as sole energy and carbon source. Growth of the pure culture was optimal at $2 \mathrm{mM}$ hydroquinone concentration. At higher concentrations, the lagphase increased considerably, and no growth occurred at concentrations higher than $10 \mathrm{mM}$. Dithionite $(100 \mu \mathrm{M})$ was always added to the growth medium before inoculation and was necessary for reliable growth. Stock cultures had to be transferred at intervals of $4-6$ weeks, and were stored at room temperature. At temperatures below $10^{\circ} \mathrm{C}$, cells lyzed within $1-2$ weeks.

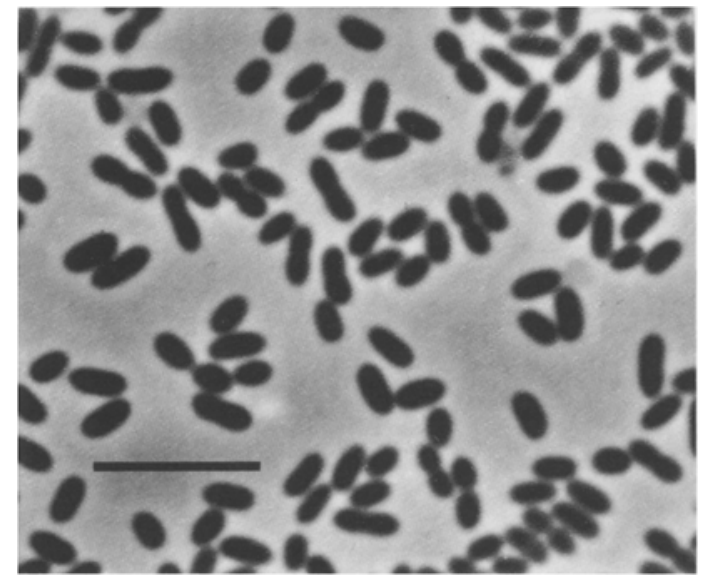

Fig. 1. Phase contrast photomicrograph of strain HQGö1 grown with hydroquinone. Bar equals $5 \mu \mathrm{m}$

Table 1. Substrates tested for growth of strain HQGö1. Substrate concentrations (in $\mathrm{mmol} / \mathrm{l}$ ) in the test cultures are given in parentheses. All growth tests were performed in duplicates

Substrates utilized:

Hydroquinone (2), benzoate (5) ${ }^{\mathrm{a}}$, gentisate (5).

Substrates not utilized:

- Formate (10), pyruvate (10), lactate (10), 3-hydroxybutyrate (10), malonate $(10)$, succinate $(10)$, malate $(10)$, citrate $(10)$, fumarate (10), caproate (10), acetoin (10), ethanol (10)

- Fructose (2), glucose (2), xylose (1), galactose (1)

- Phenol (0.5) $)^{\mathrm{a}}$, catechol (1), pyrogallol (1), phloroglucinol (1), resorcinol (1)

- Salicylate (1), gallate (2), 2,3-dihydroxybenzoate (1), nicotinate (1), protocatechuate (1)

- Cyclohexane carboxylate (1) ${ }^{\mathrm{a}}$, cyclohexanone $(1)^{\mathrm{a}}$, cyclohexanol $(1)^{a}$

- Arbutine (2)

a To these test tubes sulfate $(10 \mathrm{mM})$ and $D$. vulgaris were added

\section{Characterization of strain HQGö1}

Cells of strain HQGö1 were short rods, $0.8 \times 1.3-1.6 \mu \mathrm{m}$ in size, with rounded ends, often in pairs (Fig. 1). Formation of longer cell filaments $(10-15 \mu \mathrm{m})$ was rarely observed. Cells were always nonmotile, and no spores were formed. The Gram staining reaction was negative. The guanine-pluscytosine content of the DNA was $53.2 \pm 1.0 \mathrm{~mol} \%$. The optimal growth temperature was around $28^{\circ} \mathrm{C}$; no growth was observed above $33^{\circ} \mathrm{C}$ and below $10^{\circ} \mathrm{C}$.

\section{Physiology}

The only substrates degraded by strain HQGö1 in pure culture were hydroquinone and gentisate. In mixed cultures with either a sulfate-reducing or a methanogenic bacterium, also benzoate could be degraded (Table 1). Pure cultures converted hydroquinone to acetate and benzoate, and only traces of hydrogen $(0.2-0.5 \mu \mathrm{mol} / 1)$ were formed (Table 2$)$. Phenol was never found as intermediate or end product.

In coculture with a hydrogen-scavenging bacterium, acetate was the only organic degradation product of all three substrates, together with $\mathrm{CH}_{4}$ or $\mathrm{H}_{2} \mathrm{~S}$ (Table 3). 
Table 2. Stoichiometry of substrate fermentation by strain HQGö1 in pure culture

\begin{tabular}{|c|c|c|c|c|c|c|c|}
\hline \multirow[t]{2}{*}{ Substrate } & \multirow{2}{*}{$\begin{array}{l}\text { Amount } \\
\text { of substrate } \\
\text { provided } \\
(\mu \mathrm{mol})\end{array}$} & \multirow{2}{*}{$\begin{array}{l}\text { Cell dry } \\
\text { matter } \\
\text { formed }^{\mathrm{a}} \\
(\mathrm{mg})\end{array}$} & \multirow{2}{*}{$\begin{array}{l}\text { Substrate } \\
\text { assimilated }^{\text {b }} \\
(\mu \mathrm{mol})\end{array}$} & \multicolumn{2}{|c|}{ Products formed } & \multirow{2}{*}{$\begin{array}{l}\text { Cell } \\
\text { yield } \\
\left(\mathrm{g} \cdot \mathrm{mol}^{-1}\right)\end{array}$} & \multirow{2}{*}{$\begin{array}{l}\text { Electron } \\
\text { recovery } \\
(\%)\end{array}$} \\
\hline & & & & $\begin{array}{l}\text { Acetate } \\
\text { ( } \mu \mathrm{mol})\end{array}$ & $\begin{array}{l}\text { Benzoate } \\
(\mu \mathrm{mol})\end{array}$ & & \\
\hline Hydroquinone & 200 & 3.0 & 19.0 & 390 & 58 & 14.9 & 103.3 \\
\hline Hydroquinone & 300 & 4.4 & 27.9 & 590 & 82 & 14.7 & 101.5 \\
\hline Hydroquinone & 500 & 7.1 & 45.0 & 960 & 145 & 14.3 & 101.7 \\
\hline Gentisate & 300 & 5.6 & 35.5 & 570 & 78 & 18.5 & 100.3 \\
\hline Gentisate & 500 & 9.1 & 57.7 & 945 & 135 & 18.2 & 101.0 \\
\hline
\end{tabular}

All growth experiments were carried out at least in duplicates, in completely filled $100 \mathrm{ml}$ screw cap bottles. All values given are means of at least two independent assays in every case

a The amount of cell matter formed was calculated from OD measurements via an experimentally determined conversion factor $\left(\mathrm{OD}_{578}=\right.$ $0.1 \cong 28.5 \mathrm{mg}$ cell mass per 1$)$

b The amount of substrate assimilated was calculated using the formula:

$17 \mathrm{C}_{6} \mathrm{H}_{6} \mathrm{O}_{2}+2 \mathrm{HCO}_{3}^{-}+40 \mathrm{H}_{2} \mathrm{O} \rightarrow 26\left\langle\mathrm{C}_{4} \mathrm{H}_{7} \mathrm{O}_{3}\right\rangle+2 \mathrm{OH}^{-}$(hydroquinone)

$17 \mathrm{C}_{7} \mathrm{H}_{5} \mathrm{O}_{4}^{-}+57 \mathrm{H}_{2} \mathrm{O} \rightarrow 26\left\langle\mathrm{C}_{4} \mathrm{H}_{7} \mathrm{O}_{3}\right\rangle+15 \mathrm{HCO}_{3}^{-}+2 \mathrm{OH}^{-}$(gentisate)

Table 3. Stoichiometry of substrate fermentation by strain HQGö1 in mixed culture with Desulfovibrio vulgaris or Methanospirillum hungatei

\begin{tabular}{|c|c|c|c|c|c|}
\hline \multirow[t]{2}{*}{ Substrate } & \multirow{2}{*}{$\begin{array}{l}\text { Amount of } \\
\text { substrate provided } \\
(\mu \mathrm{mol})\end{array}$} & \multicolumn{3}{|c|}{ Products formed $(\mu \mathrm{mol})$} & \multirow{2}{*}{$\begin{array}{l}\text { Electron } \\
\text { recovery } \\
(\%)\end{array}$} \\
\hline & & Acetate & Sulfide & Methane & \\
\hline Benzoate $+D$. vulgaris & 500 & 1300 & 340 & - & 89.1 \\
\hline Benzoate $+M$. hungatei & 250 & 700 & - & 175 & 93.5 \\
\hline Hydroquinone $+D$. vulgaris & 250 & 630 & 50 & - & 83.7 \\
\hline Hydroquinone $+M$. hungate & 125 & 330 & - & 30 & 88.6 \\
\hline
\end{tabular}

${ }^{a}$ not including cell material

Experiments with $D$. vulgaris were carried out in completely filled screw cap bottles. Experiments with $M$. hungatei were carried out in serum bottles containing $50 \mathrm{ml}$ medium and $55 \mathrm{ml}$ headspace. All numbers are based on independent measurements of at least two replicate cultures in every case

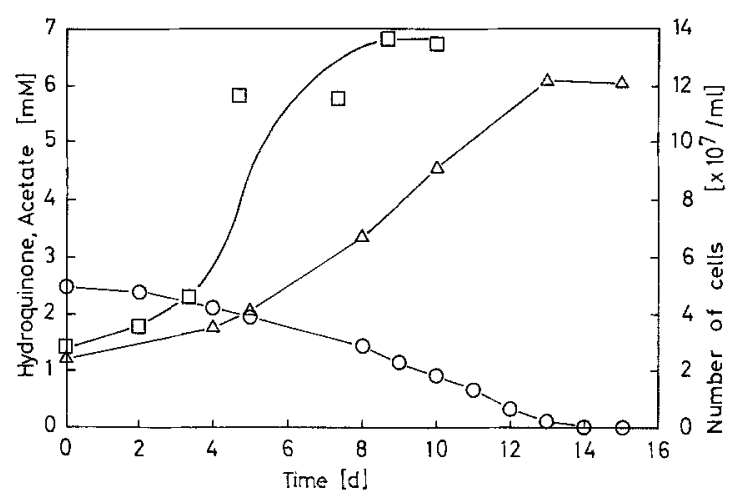

Fig. 2. Time course of hydroquinone fermentation $(O)$ and formation of acetate $(\square)$ and cell material ( $\boldsymbol{\varphi}$ by strain HQGö1. After the fifth day, the cells started to form clumps in formaldehyde-fixed slide preparations and exact cell counts were not possible any more

The growth curve (Fig. 2) shows the dependence of growth and acetate formation on hydroquinone degradation in pure culture. $2.5 \mathrm{mM}$ hydroquinone was completely degraded within 14 days, and $4.9 \mathrm{mM}$ acetate, $0.7 \mathrm{mM}$ benzoate, and $0.2-0.25 \mu \mathrm{mol} \mathrm{H}_{2} / 1$ were produced. The dependence of the hydroquinone degradation rate on the internal or external electron acceptor is shown in Fig. 3. The fastest

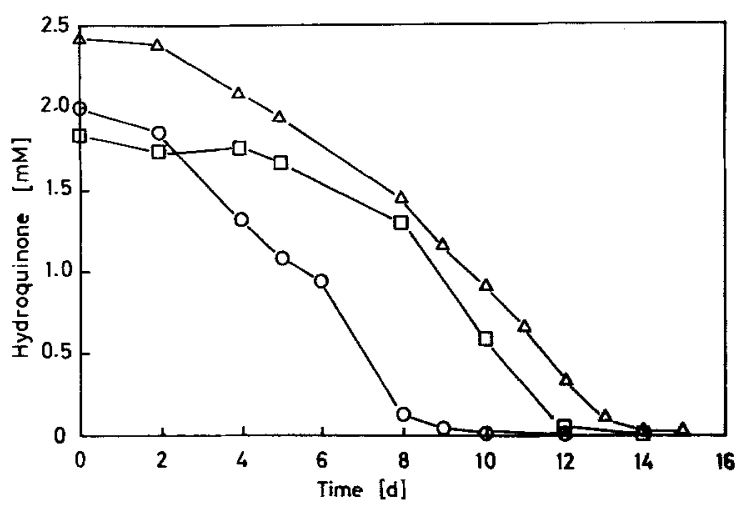

Fig. 3. Time course of hydroquinone degradation by strain HQGö1 with various electron acceptors. $\triangle$ pure culture, $\square$ coculture with Methanospirillum hungatei, $O$ coculture with Desulfovibrio vulgaris

degradation was measured in coculture with $D$. vulgaris as partner (maximum degradation rate $=0.40 \mathrm{mM} /$ day), whereas degradation in coculture with $M$. hungatei or in pure culture were lower (maximum degradation rate $=0.33$ resp. $0.25 \mathrm{mM} /$ day). Also benzoate degradation by cocultures was faster with $D$. vulgaris than with $M$. hungatei $0.50 \mathrm{mM}$ benzoate/day versus $0.43 \mathrm{mM} /$ day; data not shown). 


\section{Discussion}

Fermentative degradation of hydroquinone was so far only reported for sludge samples (Young and Rivera 1985) and for enrichment cultures (Szewzyk et al. 1985). Strain HQGö1 described in this paper is the first anaerobic fermenting bacterium degrading hydroquinone in pure culture. Besides hydroquinone, HQGö1 utilized also gentisate and, in syntrophic coculture with a hydrogen scavenging bacterium, benzoate. Phenol was not catabolized and was never detected as an intermediate during hydroquinone or benzoate degradation. Instead, benzoate was formed and accumulated as reduced product of hydroquinone fermentation. The fermentation balances (Tables 2,3) agree with the following fermentation equations (calculation of Gibbs's free energies after Thauer et al. (1977):

hydroquinone

in pure culture:

$$
\begin{aligned}
3 \mathrm{C}_{6} \mathrm{H}_{6} \mathrm{O}_{2}+\mathrm{HCO}_{3}^{-}+5 \mathrm{H}_{2} \mathrm{O} \rightarrow & 6 \mathrm{C}_{2} \mathrm{H}_{3} \mathrm{O}_{2}^{-} \\
& +\mathrm{C}_{7} \mathrm{H}_{5} \mathrm{O}_{2}^{-}+6 \mathrm{H}^{+}
\end{aligned}
$$

$\Delta \mathrm{G}_{0}{ }^{\prime}=-102.5 \mathrm{~kJ}$ (mol hydroquinone $)^{-1}$

in coculture:

$\mathrm{C}_{6} \mathrm{H}_{6} \mathrm{O}_{2}+4 \mathrm{H}_{2} \mathrm{O} \rightarrow 3 \mathrm{C}_{2} \mathrm{H}_{3} \mathrm{O}_{2}^{-}+3 \mathrm{H}^{+}+\mathrm{H}_{2}$

$\Delta \mathrm{G}_{0}{ }^{\prime}=-72.1 \mathrm{~kJ} \mathrm{~mol}^{-1}$

gentisate

in pure culture:

$3 \mathrm{C}_{7} \mathrm{H}_{5} \mathrm{O}_{4}^{-}+8 \mathrm{H}_{2} \mathrm{O} \rightarrow 6 \mathrm{C}_{2} \mathrm{H}_{3} \mathrm{O}_{2}^{-}+\mathrm{C}_{7} \mathrm{H}_{5} \mathrm{O}_{2}^{-}+2 \mathrm{HCO}_{3}^{-}$ $+6 \mathrm{H}^{+}$

$\Delta \mathrm{G}_{0}{ }^{\prime} \approx-160 \mathrm{~kJ}$ (mol gentisate $)^{-1}$

benzoate

in coculture:

$$
\begin{array}{ll}
\mathrm{C}_{7} \mathrm{H}_{5} \mathrm{O}_{2}^{-}+7 \mathrm{H}_{2} \mathrm{O} \rightarrow 3 \mathrm{C}_{2} \mathrm{H}_{3} \mathrm{O}_{2}^{-}+\mathrm{HCO}_{3}^{-} & +3 \mathrm{H}^{+} \\
\Delta \mathrm{G}_{0}{ }^{\prime}= & +91.2 \mathrm{~kJ} \mathrm{~mol}^{-1} .
\end{array}
$$

Three basic features render this bacterium interesting: i) The syntrophic oxidation of benzoate to acetate and carbon dioxide, ii) degradation of hydroquinone and gentisate in defined coculture, and iii) the reductive conversion of hydroquinone or gentisate to benzoate during fermentation of these substrates in pure culture. Syntrophic benzoate oxidation in defined culture has been reported for Syntrophus buswellii, an obligately syntrophic proton-reducing anaerobe which so far has not yet been grown in pure culture (Mountfort et al. 1984). Until now, it is not possible to decide if our isolate is related to $S$. buswellii. Lack of motility is the only feature by which strain HQGö1 can be distinguished from $S$. buswellii. Regarding the $\mathrm{G}+\mathrm{C}$-content and the limited substrate spectrum, strain HQGö1 might be related to the genus Pelobacter (Schink and Pfennig 1982).

The pathway of benzoate degradation by these fermenting bacteria has still to be studied in detail. It appears resonable that it follows basically the scheme outlined by Evans (1977). (Fig. 4). Degradation of hydroquinone and gentisate by strain HQGö1 in syntrophic cooperation with hydrogen-scavenging partner bacteria leads to three acetate residues only. Since the pure culture converts both substrates in part to benzoate it appears reasonable to assume that hydroquinone is metabolized via gentisate and not vice versa (Fig. 4). The first step of hydroquinone degradation appears to be carboxylation to gentisate, therefore.

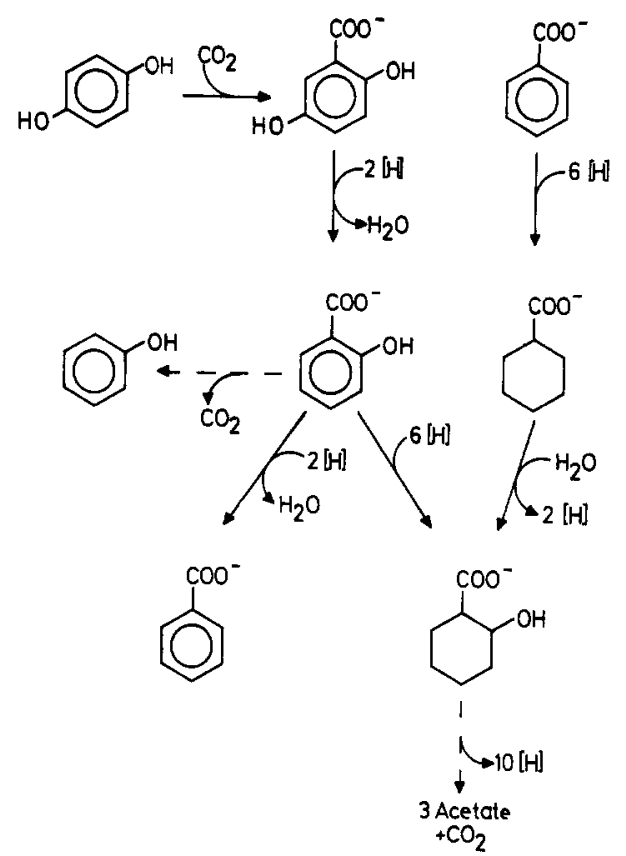

Fig. 4. Hypothetical pathway of hydroquinone, gentisate, and benzoate fermentation by strain HQGö1. Further explanation in the text

Carboxylations were recently also detected as main or by-reactions during anaerobic degradation of phenol by denitrifying bacteria (Tschech and Fuchs 1987) or by methanogenic enrichment cultures under an atmosphere of excess hydrogen (Knoll and Winter 1987). Carboxylation of the aromatic ring system might be an important reaction for the further degradation of phenolic substrates: It has been shown recently with pure cultures of denitrifying and phototrophic bacteria that reduction of benzoate to the cyclohexane carboxyl derivative occurs only after activation with Coenzyme A (Ziegler et al. 1987; Harwood and Gibson 1986). The rather complex reduction reaction transferring six electrons at once into the aromatic ring to overcome the mesomery energy probably requires this initial activation also in our fermenting bacteria.

Gentisate could go to salicylate by reductive dehydroxylation; reductive elimination of a hydroxyl group in metaposition to the carboxyl substituent was recently demonstrated in defined cocultures fermenting 3-hydroxybenzoate (Tschech and Schink 1986). Salicylate can either undergo conversion to the hydroxycyclohexane carboxyl derivative for further degradation, or be reduced to benzoate (Fig. 4). The inability of strain HQGö1 to utilize salicylate might be due to a lack of an uptake system for this compound.

As Eq. (3) shows, conversion of hydroquinone to acetate and hydrogen is an exergonic reaction under standard conditions which should allow synthesis of at least 1 ATP per reaction; nonetheless, complete oxidation of hydroquinone to acetate occurs only if a hydrogen-oxidizing partner organism keeps the hydrogen partial pressure low $(<0.5 \mu \mathrm{mol}$ $\left.\cdot 1^{-1}=10^{-2.5} \mathrm{~atm}\right)$. In pure culture, strain HQGöl uses the carboxylation and reductive conversion of hydroquinone to benzoate to dispose of electrons released during partial oxidation of hydroquinone to three acetate residues [Eq. (1), Fig. 4].

Unlike the original enrichment culture (Szewzyk et al. 1985), strain HQGö1 in defined culture never formed phenol 
as a fermentation product. The dominating non-methanogenic bacterium in the enrichment culture was morphologically similar to strain HQGö1. Therefore, phenol was probably formed in the enrichment culture by decarboxylation of salicylic acid by a further bacterium (Fig. 4). Our results obtained with the enrichment culture and the pure culture isolated thereof demonstrate again that conclusions on metabolic pathways in non-defined cultures should be drawn only very cautiously.

Acknowledgements. The authors are greatly indebted to Professor Dr. N. Pfennig for support and valuable criticism. We thank Prof. Dr. R. Conrad and H.-I. Seitz for the hydrogen measurements, Dr. J. Floßdorf, Braunschweig, FRG, for determination of GC-content, Andreas Brune, Tübingen, FRG, for HPLC-determination of benzoate, and Dr. F. Bak for helpful discussions. This work was supported by the Deutsche Forschungsgemeinschaft.

\section{References}

Bak F, Widdel F (1986) Anaerobic degradation of phenol and phenol derivatives by Desulfobacterium phenolicum sp. nov. Arch Microbiol 146:177-180

Cline JD (1969) Spectrophotometric determination of hydrogen sulfide in natural waters. Limnol Oceanogr 14:454-458

Evans WC (1977) Biochemistry of the bacterial catabolism of aromatic compounds in anaerobic environments. Nature (Lond) $270: 17-22$

Harwood CS, Gibson J (1986) Uptake of benzoate by Rhodopseudomonas palustris grown anaerobically in light. J Bacteriol $165: 504-509$

Knoll G, Winter J (1987) Anaerobic degradation of phenol in sewage sludge. Benzoate formation from phenol and $\mathrm{CO}_{2}$ in the presence of hydrogen. Appl Microbiol Biotechnol 25:384391

Krumholz LR, Bryant MP (1986) Eubacterium oxidoreducens sp. nov. requiring $\mathrm{H}_{2}$ or formate to degrade gallate, pyrogallol, phloroglucinol and quercetin. Arch Microbiol 144:8-14

Mountfort DO, Brulla WJ, Krumholz LR, Bryant MP (1984) Syntrophus buswellii gen. nov., sp. nov.: a benzoate catabolizer from methanogenic ecosystems. Int J Syst Bacteriol 34:216217

Pfennig N (1978) Rhodocyclus purpureus gen. nov. sp. nov., a ringshaped, vitamin $B_{12}$-requiring member of the family Rhodospirillaceae. Int J Syst Bacteriol 28:283-288

Schink B, Pfennig N (1982) Fermentation of trihydroxybenzenes by Pelobacter acidigallici gen. nov. sp. nov., a new strictly anaerobic, non-sporeforming bacterium. Arch Microbiol 133:195201

Seiler W, Giehl H, Roggendorf P (1980) Detection of carbon monoxide and hydrogen by conversion of mercury oxide to mercury vapor. Atoms Technol 12:40 - 45
Sleat R, Robinson JP (1984) The bacteriology of anaerobic degradation of aromatic compounds. J Appl Bacteriol 57:381-394

Szewzyk R, Pfennig N (1987) Complete oxidation of catechol by the strictly anaerobic sulfate-reducing Desulfobacterium catecholicum sp. nov. Arch Microbiol 147:163-168

Szewzyk U, Szewzyk R, Schink B (1985) Methanogenic degradation of hydroquinone and catechol via reductive dehydroxylation to phenol. FEMS Microbiol Ecol 31:79-87

Thauer RK, Jungermann K, Decker K (1977) Energy conservation in chemotrophic anaerobic bacteria. Bacteriol Rev 41:100180

Tsai CG, Jones GA (1975) Isolation and identifaction of rumen bacteria capable of anaerobic phloroglucinol degradation. Can J Microbiol $21: 794^{\circ}-801$

Tschech A, Fuchs G (1987) Anaerobic degradation of phenol by pure cultures of newly isolated denitrifying pseudomonads. Arch Microbiol 148:213-217

Tschech A, Pfennig N (1984) Growth yield increase linked to caffeate reduction in Acetobacterium woodii. Arch Microbiol 137: $163-167$

Tschech A, Schink B (1985) Fermentative degradation of resorcinol and resorcyclic acids. Arch Microbiol 143:52-59

Tschech A, Schink B (1986) Fermentative degradation of monohydroxybenzoates by defined syntrophic cocultures. Arch Microbiol 145:396-402

Widdel F (1988) Microbiology and ecology of sulfate- and sulfurreducing bacteria. In: Zehnder AJB (ed) Biology of anaerobic microorganisms. John Wiley and Sons, New York, pp 469585

Widdel F, Pfennig N (1981) Studies on dissimilatory sulfate-reducing bacteria that decompose fatty acids. I. Isolation of new sulfate-reducing bacteria enriched with acetate from saline environments. Description of Desulfobacter postgatei gen. nov., sp. nov. Arch Microbiol 129:395-400

Widdel F, Kohring GW, Mayer F (1983) Studies on dissimilatory sulfate-reducing bacteria that decompose fatty acids. III. Characterization of the filamentous gliding Desulfonema limicola gen. nov. sp nov., and Desulfonema magnum sp. nov. Arch Microbiol 134:286-294

Young LY (1984) Anaerobic degradation of aromatic compounds. In: Gibson DT (ed) Microbial degradation of organic compounds. Marcel Decker, New York, pp 487-523

Young LY, Rivera MD (1985) Methanogenic degradation of four phenolic compounds. Water Res 19:1325-1332

Ziegler K, Braun K, Böckler A, Fuchs G (1987) Studies on the anaerobic degradation of benzoic acid and 2-aminobenzoic acid by a denitrifying Pseudomonas strain. Arch Microbiol 149:6269

Received November 18, 1988/Accepted January 15, 1989 